Petro Saukh

\title{
Architectonics and Methodological Strategies of Multicultural
}

Education

Summary. Based on the critical analysis of existing concepts of multicultural education (multicultural, intercultural, transcultural, cultural and pluralistic) the new architectonics of multicultural education is suggested, with a life-giving personality paradigm in the centre. In this regard five major methodological strategies of multicultural education, which serve as benchmarks and major sources, are justified.

The issues of the implementation of the multicultural education project in Ukraine that do not contribute to the harmonization of public life and intercultural dialogue and understanding are outlined.

Key words: multiculturalism, multicultural education, identity, nation consolidating values, cultural and historical memory, cultural and ethnical narcissism, positive discrimination, democratic and egalitarian policy.

The problem of intercultural interaction has become a focus of attention of politicians, philosophers, specialists in culture studies as well as of a wide pedagogical community. In this regard, the necessity for multicultural education and training in many countries becomes the strategy of great significance. In numerous documents of the United Nations Organization, UNESCO, the Council of Europe, it is emphasized that one of the most important functions of modern education is a task to teach people to live together, to help them transform the growing interdependence of countries and ethnic groups into conscious solidarity. For this purpose education should help to ensure that, on the one hand, people have realized their roots and thus can determine their actual place in the world, but, on the other hand, it should foster respect for other cultures.

But we must frankly say that despite the importance of the problem and the status of its certain aspects, there is no coherent concept of multicultural education 
in the world pedagogical theory and practice. The Croatian cultural specialist Sanjin Dragojević summarising achievements of the study on the issues of intercultural interaction between the members of educational process, states that in the world today there are at least four basic concepts of multicultural education:

(1) multicultural education which is focused not on intercultural exchange and mutual interaction but on culture preservation of existing ethnic minorities;

(2) intercultural education which is aimed at ensuring an active, positive dialogue of cultures and their mutual understanding and enrichment;

(3) transcultural education which is focused on the system of values formed at the supranational (transnational) level;

(4) cultural and pluralistic education, the core idea of which is respect and support of all existing cultural needs and lifestyles existing in society (not only ethnic, linguistic, religious cultures, but also regional, corporate, gender ones, etc.). ${ }^{1}$

Each of these concepts pursues a noble goal, but none of them is able to fully ensure the implementation of today's paramount formula 'world unity and culture diversity'. In fact, success in its solution much depends on how well the balance between the poles of this formula is built. Why do I think so? First of all, in most of these concepts, cultural identity is inevitably correlated with national identity. There the nation falls into a snare of transnationalism or ultranationalism, and the culture faces the situation of multiculturalism that causes limitations of these concepts. Secondly, what escapes their attention is that the identity today is characterized by considerable dynamism, plurality and contextuality. Today there arises, so to speak, 'the complication of identity mechanisms'. ${ }^{2}$ Identity is not a quality that is inherent in people from birth, this is a processuality and freedom of individual choice. It means that the concept of multicultural education can succeed only when it is based on the implementation of the ideas of respect to each

\footnotetext{
${ }^{1}$ Гриценко О.А., Гончаренко Н.К., Мягка С.А. Українські типології меншин // [Електронний ресурс]. Режим доступу: http://www.Culturalstudiens.in.ua.

2 Саух П.Ю., Саух Ю.П. Мультикультурализм: блеск теории и практическая несостоятельность проекта в дискурсе реальных процессов межкультурного взаимодействия // Евразийство и мир, № 3, 2014. - С. 41.
} 
individual as self-worth. Global culture and the culture of tribalism whose conceptual principles serve as the basis for existing concepts cannot overcome the dislike for otherness because they don't manifest the value of the individual as the highest earthly value. 'Globalism and tribalism,' as Benjamin Barber rightly mentions, 'are tearing the contemporary world apart'. ${ }^{3}$

In this situation, the architectonics of multicultural education should be built on the cultural and anthropological matrix which guides the educational process towards the dialogue with the culture of a person as its creator and subject capable of cultural self-development. The modern individual is at the boundary of cultures, interaction with them requiring dialogical communication, understanding and respect for the cultural identity of other people. And this is not about ethnic groups, nations or religions, but about their particular representatives. It is quite understandable that it is not nations that make friends, it is people who represent them. In other words, the architectonics of multicultural education should be aimed at a person and focused on culture. Its goal is a person who explores and creates their own cultural world through the dialogue with the internal and external cultural environment. Intercultural communication built on this life-giving basis causes a special communication field of semantic overlap. In the process of communication with 'the Other' and their culture, interaction of the individual with certain social roles, values, norms and customs, attitudes and expectations which the personality has to choose and reproduce to reach identity in the difficult process of mutual recognition is shown. The social stock of knowledge gained by a person in the process of intercultural communication acts as a prerequisite for accepting and understanding 'the Other', communicating with them, and places at their disposal the typing schemes required for most daily affairs of everyday life, and as a result, causes the formation of their personal 'I' based on the balance between individual and civic identity. Definitely, this by no means distorts the national identity.

\footnotetext{
${ }^{3}$ Barber B. Fihand vs. Mc. Word: How Globalism and Tribalism are Reshaping the World. - New York: Ballantiwe, 1996. - p. 432.
} 
This means that the architectonics of multicultural education should be based, firstly, on the principles of dialogic communication, openness and tolerance. Today we are to teach people to appreciate the diversity of cultures and to carry it out through the dialogue rather than synthesis in which there is a hidden danger of losing opportunities for their further development. And above all, it is through dialogue that we get the opportunity to establish a real reciprocity and avoid 'domination - submission' (J. Derrida), the negative consequences of which are so evident today. Secondly, it has to rely on the principle of personality-centredness which focuses not on artificial preservation of the way of life of a nation, but on giving each individual (not just people in general) the right to free cultural selfdetermination. Culture, as we go forward, will be developing in the direction of individual rather than national differences and features that feed the cultural heritage of all nations. No matter how much anybody may want racial, cultural or religious 'purity' today, we are destined to live in 'the common house' in the future, having laid the foundations for life-giving intercultural coexistence.

In order to be life-giving, the architectonics of multicultural education should be built, in my opinion, on the following (at least five) important methodological strategies. First of all, it is reliance on nation consolidating values. Understanding of the values by different ethnic groups may vary and often quite significantly. But in spiritual matters, as we know, there are always values significant for everybody that not only do not cause controversy between representatives of different nationalities, but also find understanding and support among them. These nation consolidating values should be the ones that determine general cultural values for the majority of people, for instance, aversion to lack of freedom, protection of dignity and rights of every person, desire for selfactualisation, etc. (which, by the way, are not amenable to time erosion). Only on this basis, mechanisms of the semantic augmentation, mutual exchange of values and mutual understanding can be built. The ability of humankind to become truly human community, united not only by common global threats, but also by joint 
actions and common semantic field, which could be called a global outlook, depends on the effectiveness of their implementation.

The second methodological strategy of multicultural education should become the critical and analytical attitude to the cultural and historical memory as a representative form of reality. Culture as the world of our existence is permeated with memory, which is entwined with the modern era. Any sociocultural transformation (such as we are experiencing today) is associated with the appeal to the past. Each appeal enriches the present, in its own way understands it, forming the necessary basis for moving forward. Retrospection of each nation, if it wasn't caused by the desire to keep separate from other people and their cultural experience, was fruitful in the reason it enriched, diversified and expanded their cultural horizons. But it shouldn't be forgotten that a noncritical and picky look into the depths of history often negatively affects the process of cross-cultural interaction, 'creates conditions for deformations of historical memory and temptation for the corresponding national and cultural obliquity'. ${ }^{4}$ Obsession with the past, its idealization, an attempt to build a 'Future-in-the-Past' lifestyle is a dangerous political and cultural strategy.

The third valuable methodological strategy of multicultural education should be eradication of cultural and ethnic narcissism that determines cultural and educational isolation. Unfortunately, most of the concepts of multicultural education, so to speak, reside in western political correctness, of which conservation of 'colonial viewpoint of White majority' ${ }^{5}$ is typical. It seems to me that this political correctness bears very repressive dominant, imposing certain standards. The key metaphor of these standards is nothing but the metaphor of minorities, as though we are admiring minorities. This admiration is the preservation, it is closely related to narcissism. Narcissus does not see the other, there are only his projections, the projections of his own culture. In the effective

\footnotetext{
${ }^{4}$ Саух П.Ю. Сучасна освіта: портрет без прикрас: Монографія. - Житомир: Вид-во ЖДУ ім. І. Франка, 2012. - С. 140.

${ }^{5}$ Макбрайд В. Викладання соціальної та політичної філософії з точки зору західної і незахідної перспектив // Філософія освіти. № 1-2, 2011. - С. 12.
} 
educational interaction, it is important to understand, see and hear not the minor, but the other. If we don't see the other, then conditions for producing the centre and the periphery are cultivated. On this basis, there cannot be any effective multicultural education. Today the Other hitherto not dominant or marginalized cultures strive for the equal place at the round table of the world. They are ambitious and dynamic, with a strong sense of dignity and self-worth. Despite the fact that different cultures vary by levels of influence, none of them wants to be just tolerated. Every culture considers its basic values to be universal ones (if it ceases to do so, then it will disappear as an independent culture!). They want to be considered. Tolerance is certainly a value, but an intermediate one. Nobody would like to be merely 'tolerated' . Therefore, these other cultures do not accept and cannot accept the so-called 'positive discrimination' (i.e. the efforts to create certain benefits and preferences for peripheral cultures). These multicultural practices aiming at the restoration of social justice, do not only hinder intercultural understanding, but also distort the global context for the development of educational strategies.

The fourth methodological strategy of multicultural education with its accentuation on cultural differences and increased cultural sensibility should be the individualization of education. Under this condition, education appears to be the state of open opportunities for self-actualisation. In modern education, all participants of the educational process - teachers, pupils and students - should become 'transgressors'. The act of transgression means overcoming the boundaries between the possible and impossible, going beyond their cultural and semantic field, and thus getting closer to understanding the Other. As the result of transgression, common cognitive fields are established, where there is mutual understanding, redefinition of signs, demystification of stereotypes and formation of tolerance zones.

\footnotetext{
${ }^{6}$ Саух П. Сучасні виклики глобалізованої епохи: суспільство і церква в пошуках відповідей // Україна і Ватикан: до і після Другого Ватиканського Собору. Науковий збірник. - К.: УАР, 2013. - С. 21.
} 
Finally, the fifth important fundamental strategy of multicultural education is a combination of theory and praxis. The link between multicultural education projects and state policy is very important for ensuring equality and fairness for different groups of people. Instead of pretending that education is isolated from politics, multicultural education should combine learning materials and processes with the imperatives of a democratic society. It can be successful only when it expands rights and opportunities of people and transforms society. Participation of the members of multicultural education process in social movements' activities, voluntary associations, non-governmental organisations helps to understand oneself and the Other better, to look at things through the eyes of other people. Combining theory and practice, knowledge with actions provides an opportunity to experience the ways of impact of society on people and feel the relations between such cultural identifiers as race, ethnicity, religion, gender, sexual orientation, social class, language, (in) capacity, age, and many others in real life.

Problems of multiculturalism and the implementation of multicultural political projects that form the global context for the development of modern educational strategies are particularly relevant for Ukraine. The reason is simple. Ukraine is a multi-ethnic, multi-religious, multi-lingual and multi-cultural country that is closely related to the intensive development of global integration processes. Representatives of more than 130 nations and nationalities that have their own cultural traditions, national identity and religious faith live here. Furthermore, in Ukraine, as well as worldwide, there is a large-scale process of identification mechanisms getting more and more complicated. National identity now coexists here with professional, gender, religious and regional identities that are often hardly compatible with the former. And most significantly, ethnic groups that haven't previously had a chance to be seen and heard, enter the Ukrainian sociocultural arena. Their identity becomes valuable and, therefore, it appears to be a cultural resource for society, which should be considered by the state.

But in spite of this and the current tragic situation in Ukraine, the issue of multicultural policy in public and scholarly discussions is scarcely debated. The 
attention of the political and cultural elite is concentrated on the problems of the state and nation building; within this context multiculturalism is very often seen as a minor or even disappointing factor that complicates the understanding of modern Ukrainian national statehood. Under the present conditions, Ukrainian society shows the unwillingness to implement a multicultural model of nation building inside of it.

The theoretical results in the field of multicultural education, which in some cases are put into practice, mainly gravitate to the so-called intercultural concept where cultural is understood as ethnic and the ethnic model is based on essentialist view (the idea of concentrated solution). As a result, cultural boundaries between the groups leave no doubt and the differences are rigidly fixed and overemphasised, paving the way for xenophobia. Every single ethno-cultural group is attributed to non-existent homogeneity, autonomous subjectivity within which the subjectivity of the individual is levelled, causing deindividualisation and leading to human rights violations in practice. Hence, dogma-demand 'Think Ukrainian', which actually prohibits thinking differently, transcending native, cosy, good home culture, exposing it to reflection. On this basis, it is impossible to form a transcultural space where people freed from 'the captivity' of native culture are ready to meet with another potential 'I'. Under this condition, a different culture can be perceived as a certain possibility of their own culture. After all, when we include our own abilities to be different into the communication space, it becomes transcultural, structural and communicative space for future creation, but not the preservation of multicultural differences or simply a tolerant attitude to differences.

The absence of a clearly defined concept of multicultural education in Ukraine, attraction to intercultural policy whose goal is (with the help of the state) a simple assimilation of cultural features and traditions of minor ethnical groups, actually governs their lives, limits their right for bigger cultural self-determination. Thereby Ukraine turned out to be outside of the 'politics of recognition' (Charles Taylor), which is the result of the transition from hierarchical society to a society dominated by the principle of free citizenship as a regulative ideal. The principle of 
self-preservation of any national culture, and humanity in general, lies in an individual's self-transformation. And this is not even about universal human values, but of humanism in itself, which implies respect, trust and love. Values of all ideologies, political doctrines, and even religions are ultimately relative. Only the value of life is not relative. Only in connection with this fundamental value they get validity for each personality, only through its mediation they can be experienced and perceived by a human being.

Multicultural education as a social innovation should be linked with the answer to the question 'Who and what should we become?' rather than questions 'Who are we?' or 'Where did we come from?'. The practical implementation of this project is possible through the democratic and egalitarian policy that not only defends the preservation of cultural diversity via state intervention, but also maximises people's participation in the processes of intercultural dialogue and communication. Only this approach can incorporate all socio-cultural groups into the civil society for the reason that it is a serious obstacle for cultural nationalism that absolutises differences, and for cultural imperialism that ignores them.

\section{Bibliography}

Barber B. Fihand vs. Mc. Word: How Globalism and Tribalism are Reshaping the World. - New York: Ballantiwe, 1996.

Гриценко О.А., Гончаренко Н.К., Мягка Є.А. Українські типології меншин // [Електронний ресурс]. - Режим доступу:

http://www.Culturalstudiens.in.ua.

Макбрайд В. Викладання соціальної та політичної філософії з точки зору західної і незахідної перспектив // Філософія освіти. № 1-2, 2011.

Саух П.Ю. Сучасна освіта: портрет без прикрас: Монографія. - Житомир: Вид-во ЖДУ ім. I. Франка, 2012.

Саух П. Сучасні виклики глобалізованої епохи: суспільство і церква в пошуках відповідей // Україна і Ватикан: до і після Другого Ватиканського Собору. Науковий збірник. - К.: УАP, 2013.

Саух П.Ю., Саух Ю.П. Мультикультурализм: блеск теории и практическая несостоятельность проекта в дискурсе реальных процессов межкультурного взаимодействия // Евразийство и мир, № 3, 2014. 